\title{
Reduced bone mass accrual in mouse model of repetitive mild traumatic brain injury
}

\author{
Hongrun Yu, PhD; Jon E. Wergedal, PhD; Charles H. Rundle, PhD; Subburaman Mohan, PhD* \\ Musculoskeletal Disease Center, Department of Veterans Affairs Loma Linda HealthCare System, Loma Linda, CA; \\ Department of Medicine, Loma Linda University, Loma Linda, CA
}

\begin{abstract}
Traumatic brain injury (TBI) can affect bone by influencing the production/actions of pituitary hormones and neuropeptides that play significant regulatory roles in bone metabolism. Previously, we demonstrated that experimental TBI exerted a negative effect on the skeleton. Since mild TBI (mTBI) accounts for the majority of TBI cases, this study was undertaken to evaluate TBI effects using a milder impact model in female mice. Repetitive mTBI caused microhemorrhaging, astrocytosis, and increased anti-inflammatory protective actions in the brain of the impacted versus control mice 2 wk after the first impact. Serum levels of growth regulating insulin-like growth factor 1 (IGF-1) were reduced by $28.9 \%$. Bone mass was reduced significantly in total body as well as individual skeletons. Tibial total cortical density was reduced by $7.0 \%$, which led to weaker bones, as shown by a $31.3 \%$ decrease in femoral size adjusted peak torque. A $27.5 \%$ decrease in tibial trabecular bone volume per total volume was accompanied by a $34.3 \%(p=0.07)$ decrease in bone formation rate (BFR) per total area. Based on our data, we conclude that repetitive mTBI exerted significant negative effects on accrual of both cortical and trabecular bone mass in mice caused by a reduced BFR.
\end{abstract}

Key words: bone mineral content, bone mineral density, histology, histomorphometry, mice, micro-computed tomography, mild traumatic brain injury, torsion test, traumatic brain injury, weight drop model.

\section{INTRODUCTION}

Traumatic brain injury (TBI) is an increasingly important public health issue and a major cause of death and disability worldwide. Its severity is determined based on the length of loss of consciousness and other neurological problems that occur following the insult [1-2]. According to a current estimate from the Centers for Disease Control and Prevention, approximately 1.7 million people experience one TBI each year in the United States. Mild TBI (mTBI) accounts for almost 85 percent of all TBI cases [3]. Similar data are obtained by the U.S. military: 2013 statistics from the Defense and Veteran Brain Injury Center showed that more than 280,000 servicemembers had sustained a TBI since the year 2000, and 82 percent of these cases were mTBI. Special attention should be paid to those servicemembers with multiple brain traumas that would have a cumulative effect during their tours of duty. Repeat brain injury is also

\footnotetext{
Abbreviations: $\mathrm{BFR}=$ bone formation rate, $\mathrm{BV}=$ bone volume, GFAP = glial fibrillary acidic protein, GH = growth hormone, Hsp70 $=70 \mathrm{kDa}$ heat shock protein, IBA1 $=$ ionized calcium-binding adapter molecule 1 , IGF-1 = insulin-like growth factor 1 , micro-CT = micro-computed tomography, $\mathrm{mTBI}=$ mild traumatic brain injury, RT-PCR $=$ reverse transcription polymerase chain reaction, $\mathrm{T} . \mathrm{Ar}=$ total area, $\mathrm{TBI}=$ traumatic brain injury, Tb.N = trabecular number, Tb.Sp = trabecular separation, $\mathrm{TV}=$ total volume, $\mathrm{VA}=$ Department of Veterans Affairs.

*Address all correspondence to Subburaman Mohan, PhD; Musculoskeletal Disease Center, VA Loma Linda Healthcare System, 11201 Benton St (151), Loma Linda, CA 92357; 909-825-7084, ext 6180; fax: 909-796-1680.

Email: Subburaman.mohan@va.gov

http://dx.doi.org/10.1682/JRRD.2014.04.0095
} 
prevalent in professional sports; 60 percent of retired football players sustained concussions during their career, and approximately 25 percent of them had repeat injury [4-5]. Animal studies indicate that repetitive mTBI is associated with more severe neurological, pathological, and behavioral changes than single mTBI [6-7]. Furthermore, these changes evolve long after the initial injuries, recapitulating many features of human TBI. The functional impairment associated with TBI is multifold, and not only cognitive, emotional, and behavioral, but also physical [8-9]. Since physical activity is important in building and maintaining healthy bones, it is predicted that TBI could influence the skeletal system negatively.

One way TBI contributes to functional impairment is to cause endocrine dysfunction through the hypothalamus [10]. The hypothalamus acts to link the nervous system to the endocrine system via the pituitary gland. The hypothalamus and pituitary glands are tightly integrated in the brain, and damage to the hypothalamus following TBI will affect normal functions of the pituitary. Pituitary dysfunction is relatively common following TBI [11-12] and present in 25 to 70 percent of the patients following a moderate-to-severe TBI [10]. A common form of pituitary dysfunction is hypopituitarism, i.e., deficiencies of pituitary hormones such as growth hormone (GH), gonadotropins, thyroid-stimulating hormone, and adrenocorticotropic hormone [13-14]. Pituitary hormones such as $\mathrm{GH}$ and downstream players such as liver-produced insulin-like growth factor 1 (IGF-1) are important regulators of bone formation and contribute to peak bone mass [15-19]. Therefore, reduced production and secretion of pituitary hormones following TBI can negatively affect normal skeletal development.

Besides pituitary hormones, there are neural signals that may place the skeletal system under central control of the hypothalamus. Presumably, these signals relay the negative effect of TBI from the hypothalamus directly to local bone cells. One example is leptin, an adipose tissuederived hormone. Previous studies showed that compared with wild type mice, cancellous bone mass was increased in leptin-deficient $o b / o b$ mice [20] and was decreased in leptin transgenic mice [21]. Central administration of leptin to the brain was able to correct the cancellous bone changes in $o b / o b$ mice at doses that were ineffective when administered peripherally, indicating a pathway originating from the brain [20]. Furthermore, chemical lesions of neurons in the hypothalamus recapitulated the $o b / o b$ phenotype and abrogated the effect of central leptin adminis- tration [22]. In contrast to the inhibitory effects of central leptin on bone formation, other studies have demonstrated an important role for peripheral leptin in stimulating bone formation [e.g., 23-24]. There are other signal systems that may also serve as neural output from the hypothalamus to bone tissues, including the neuropeptide $\mathrm{Y}$ and the cannabinoid receptors systems [25].

In a previous study using a mouse repetitive closed head injury model, we evaluated the effect of experimental TBI on the skeletal system [26]. However, there was a high animal mortality rate because of severe impact parameters used in that study, making the model somewhat different from human TBI where the majority of the cases are mTBI. Therefore, it would be necessary to determine the effects of TBI on the skeletal system using a milder impact model that mimics more closely the brain situation that occurs in the majority of human mTBI patients. Here, we hypothesized that by influencing the production/actions of pituitary hormones and neuropeptides that have significant regulatory functions in bone metabolism, mTBI could adversely affect the skeletal system. Indeed, the findings of this study revealed that repetitive TBI even in a mild form exerted significant negative effects on bone mass, bone structure, and bone strength.

\section{METHODS}

\section{Animals}

We purchased 4 wk old female C57BL/6J mice from the Jackson Laboratory (Bar Harbor, Maine). The mice were allowed $1 \mathrm{wk}$ to acclimate to the local environment before experiments were performed. All animals were housed in the Veterinary Medical Unit of the Department of Veterans Affairs (VA) Loma Linda HealthCare System under the standard conditions of $14 \mathrm{hr}$ of light, $10 \mathrm{hrs}$ of darkness, with an ambient temperature of $20^{\circ} \mathrm{C}$ and a relative humidity of 30 to 60 percent.

\section{Traumatic Brain Injury Protocol}

The apparatus and TBI protocol were described in a previous study [26]. In this study, we used a 95 g drop weight and $1 \mathrm{~m}$ drop height, which were the same as described by Kane et al. for a repetitive mTBI model [27]. As before, weight drop impacts on experimental mice were carried out under isoflurane anesthesia, and control mice received only isoflurane anesthesia. A total of 18 mice (9 experimental and 9 control) were used. The 
impact to the experimental mice or isoflurane exposure for the control mice was carried out for four consecutive days, one time per day.

\section{Tissue Collection and Processing}

In vivo bone parameters of total body and specific skeletal tissues were measured on anesthetized mice 1 and 2 wk after the first impact. After the second measurement, both impacted and control mice were immediately euthanized. Trunk blood, brain, tibias, and femurs were collected. Trunk blood was centrifuged at $10,000 \mathrm{~g}$ for $15 \mathrm{~min}$ at $4^{\circ} \mathrm{C}$. The serum was stored at $-70^{\circ} \mathrm{C}$ for IGF-1 assay. The left brain was fixed in 4 percent formaldehyde for $48 \mathrm{~h}$ and stored in $1 \times$ phosphate buffered saline for histology. The right brain was stored at $-70^{\circ} \mathrm{C}$ for gene expression analysis. Left tibia, right tibia, and left femur were fixed in 4 percent formaldehyde for $48 \mathrm{~h}$ and preserved in $1 \times$ phosphate buffered saline. Both tibias were first used for micro-computed tomography (micro-CT) analysis, followed by histomorphometric analysis of the metaphyseal region. The left femur was used for bone strength testing. The following procedures were used as previously described: in vivo bone parameter measurements [28-29], serum radioimmunoassay for IGF-1 [30-31], micro-CT analysis [30-32], and histomorphometric analysis [32-33]. Other procedures employed are described subsequently.

\section{Brain Gene Expression Analysis}

RNA was extracted and real-time reverse transcription polymerase chain reaction (RT-PCR) analysis were carried out as previously described for bone [31]. The DNA sequences for the mouse primers were obtained from PrimerBank (http://pga.mgh.harvard.edu/primerbank/) and are listed in Table 1. We analyzed genes for ionized calcium-binding adapter molecule 1 (IBA1), glial fibrillary acidic protein (GFAP), and the $70 \mathrm{kDa}$ heat shock protein (Hsp70).

\section{Brain Histological Analysis}

The left brain was embedded in paraffin. Dorsalventral sectioning of the brain samples was carried out at a thickness of $10 \mu \mathrm{m}$. The orientation of the brain section was marked with a tissue-marking dye. The brain sections were then mounted on slides and stained. Prussian blue is a stain that identifies iron in brain tissues, indicating presence of a minor hemorrhage [34]. The Gomori modification of the Perls method was used for Prussian blue staining [35]. One
Table 1.

Primers used in real-time reverse transcription polymerase chain reaction.

\begin{tabular}{|c|c|c|}
\hline Gene & $\begin{array}{c}\text { Primer } \\
\text { Direction }\end{array}$ & Primer Sequence \\
\hline \multirow[t]{2}{*}{$\overline{\text { GFAP }}^{*}$} & Forward & 5'-CGGAGACGCATCACCTCTG \\
\hline & Reverse & 5'-AGGGAGTGGAGGAGTCATTCG \\
\hline \multirow[t]{2}{*}{ IBA1 $^{\dagger}$} & Forward & 5'-ATCAACAAGCAATTCCTCGATGA \\
\hline & Reverse & 5'-CAGCATTCGCTTCAAGGACATA \\
\hline \multirow[t]{2}{*}{ Hsp70 } & Forward & 5'-TGGTGCAGTCCGACATGAAG \\
\hline & Reverse & 5'-GCTGAGAGTCGTTGAAGTAGGC \\
\hline \multicolumn{3}{|c|}{$\begin{array}{l}{ }^{*} \text { Primers amplify both transcript variant } 1 \text { and } 2 \text {. } \\
{ }^{\dagger} \text { Also called allograft inflammatory factor } 1 . \\
{ }^{\dagger} \text { Refers to both heat shock protein (Hsp) } 70-3 \text { (also called Hspa1a) and Hsp70-1 } \\
\text { (also called Hapa1b) with } 99 \% \text { identity in amino acid sequence. Primers } \\
\text { amplify both genes. } \\
\text { IBA1 = ionized calcium-binding adapter molecule, GFAP = glial fibrillory } \\
\text { acidic protein. }\end{array}$} \\
\hline
\end{tabular}

section from each animal with two major staining areas was scored. Scoring was carried out under a microscope at $10 \times$ magnification with a maximum score of 5 for each area and 10 for each section.

Cresyl violet staining was used to demonstrate the nissl substance in the neurons and cell nuclei and was used, in this case, to identify neurons. Staining was conducted according to the nissl staining protocol with paraffin sections from brain and spinal cord described in IHC World (Ellicott City, Maryland) (http://www.ihcworld.com). We scored one section for each animal. Besides visual examination of the section under the microscope for amyloid formation and neuron damage, the section was photographed at $4 \times$ magnification on a $3.93 \mathrm{~mm}^{2}$ area in the middle of the cortex region that was devoid of denta gryrus. The total number of neurons in the area was estimated using Image-Pro Plus software (Media Cybernetics; Rockville, Maryland).

\section{Bone Strength Test}

Bone strength was determined using a torsion test. We adapted an Instron DynaMite 8841 servohydraulic materials testing apparatus (Instron; Canton, Massachusetts) in conjunction with the use of the Partner Universal Materials Testing software to perform the strength test on the left femur. First, the femoral epiphyses were cast in a dental resin using a custom mold, which was designed to shape the cast product to fit the 3-jaw chucks in the Instron test apparatus. During the torsion test, the epiphyses were completely immobilized in the chucks, and the diaphysis was accurately aligned. The bone was then twisted around the diaphyseal axis at a constant rate $(1 \%$ s) until a break, 
which was expected to take place at the weakest point of the bone. The strength of the bone was determined by the ultimate load at failure, i.e., peak torque and angle at the peak torque.

\section{RESULTS}

\section{Brain}

Histological analysis of the brain sections showed that the impacted mice had significantly higher Prussian blue staining scores than the control mice (2.3 vs $0.6, p=$ 0.02) (Figure 1), indicating that more brain areas of the impacted mice had iron deposits, i.e., microhemorrhage. However, the majority of the staining was localized in only a few areas. There appeared to be no visible damage to the brain neurons because the cresyl violet staining showed neither amyloid formation nor apoptotic neurons in the brain sections of the impacted and control mice. In addition, there was no significant difference in the number of neurons between the impacted and control mice $\left(1,350.6\right.$ vs $\left.1,429.7 / \mathrm{mm}^{2}, p=0.29\right)$ (Figure 2). Real-time RT-PCR analysis of two genes recognized as glial cell

(a)

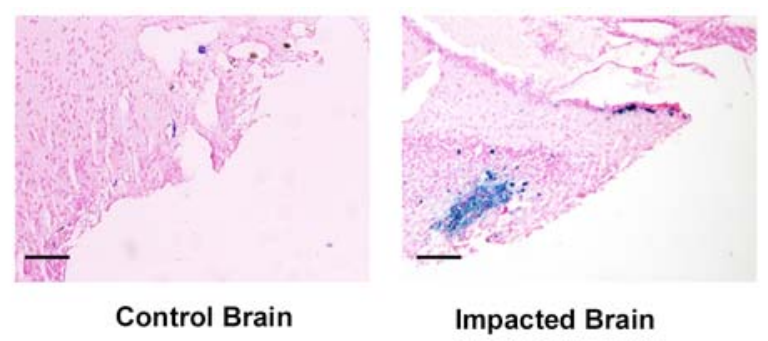

(b)

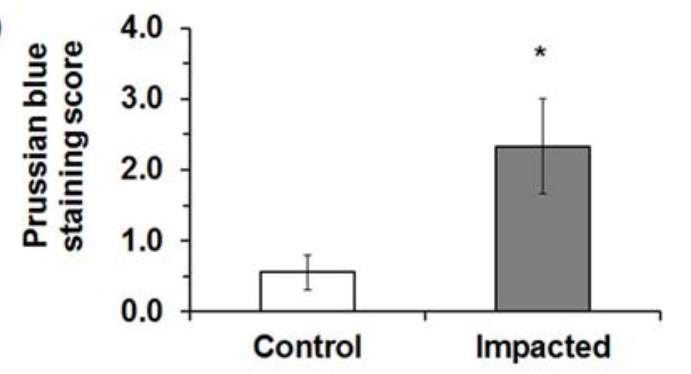

Figure 1.

Prussian blue staining of brain sections for iron deposition. (a) Images of representative brain sections of impacted and control mice at 10× magnification. Calibration bar represents $100 \mu \mathrm{m}$.

(b) Staining scores of impacted and control mice. Values are group means and standard error of mean. *Significant at $p<0.05$ versus control mice based on $t$-test. responders following TBI showed that expression of IBA1 did not change (Figure 3). However, there was a significant increase in the expression of GFAP $(68.0 \%$, $p=0.02)$ in the impacted versus control mice. Another gene, Hsp70, showed significant upregulation (89.7\%, $p=0.05)$ in impacted mice.

\section{Body and Serum Insulin-Like Growth Factor 1}

There were no significant differences in weekly body weight measurements between the impacted versus control mice (data not shown). While the body mass composition was not different between the two groups of mice at the end of the first week, there was a significant reduction in lean body mass $(1.8 \%, p=0.04)$ and a significant increase in fat content $(9.0 \%, p=0.04) 2 \mathrm{wk}$ after the first impact (Figure 4). The mTBI impact also caused a significant 28.9 percent decrease in the circulating IGF-1 levels in the impacted versus control mice (322.0 vs $452.7 \mathrm{ng} / \mathrm{mL}, p=0.05$ ) (Figure 5).

\section{Bone Mass Accrual}

In vivo bone parameter measurements at $2 \mathrm{wk}$ after the first impact showed that total body, lumbar vertebrae,

(a)
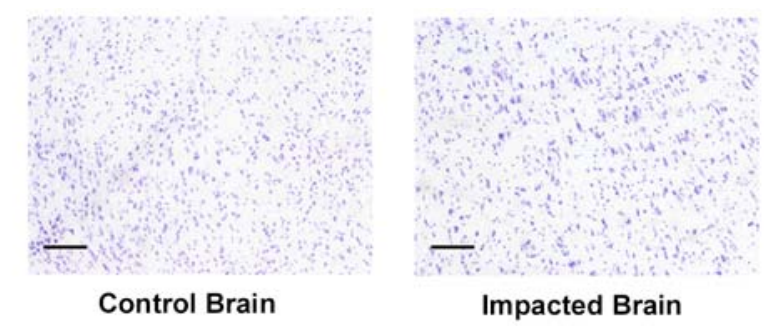

(b)

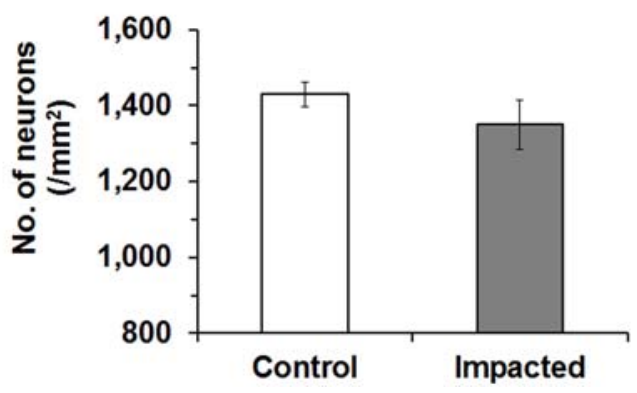

Figure 2.

Cresyl violet blue staining of brain sections for neuron damage. (a) Images of representative brain sections of impacted and control mice at 10x magnification. Calibration bar represents $100 \mu \mathrm{m}$. (b) Estimated numbers of neurons in brains of impacted and control mice. Values are group means and standard error of mean. 


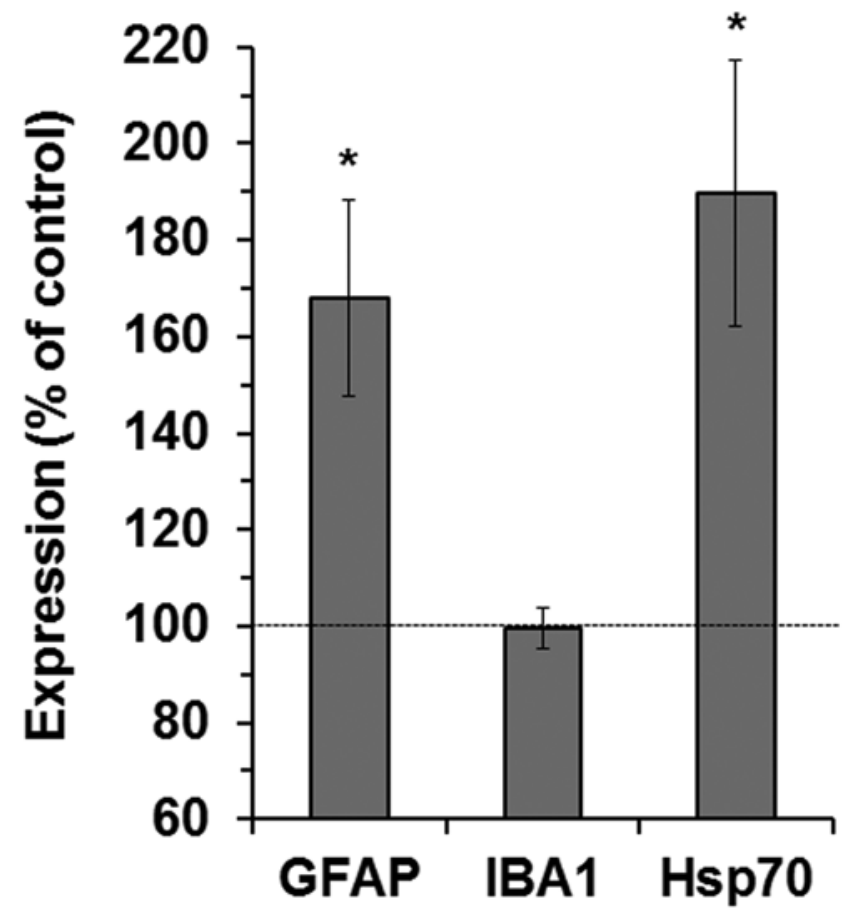

Figure 3.

Real-time reverse transcription polymerase chain reaction analysis of brain injury and healing associated marker genes. Fold changes in impacted mice were converted to percentages of control mice. Values are group means and standard error of mean. * Significant at $p<0.05$ between impacted and control mice based on $t$-test. GFAP = glial fibrillary acidic protein, Hsp70 = $70 \mathrm{kDa}$ heat shock protein, IBA1 = ionized calciumbinding adapter molecule 1.

femur, and tibia all had significant reductions in bone mineral content (from $10.3 \%$ in femur to $18.8 \%$ in lumbar vertebrae; $p=0.00-0.04$ ) and bone mineral density (from $5.7 \%$ in total body to $13.7 \%$ in lumbar vertebrae; all $p<$ 0.01 ) in the impacted versus control mice (Figure 6).

\section{Cortical Structure}

Micro-CT analysis of the middiaphyseal region of the tibia showed that there was no change in total bone volume (TV), suggesting that bone size had not changed in the impacted mice (Figure 7) (all comparisons made to the control mice in the article). However, the impacted mice showed a significantly reduced bone volume (BV) $(6.9 \%, p=0.01)$ and total density $(7.0 \%, p=0.01)$. Torsion test of the femur showed that the break angle was not significantly different (Figure 8). However, the

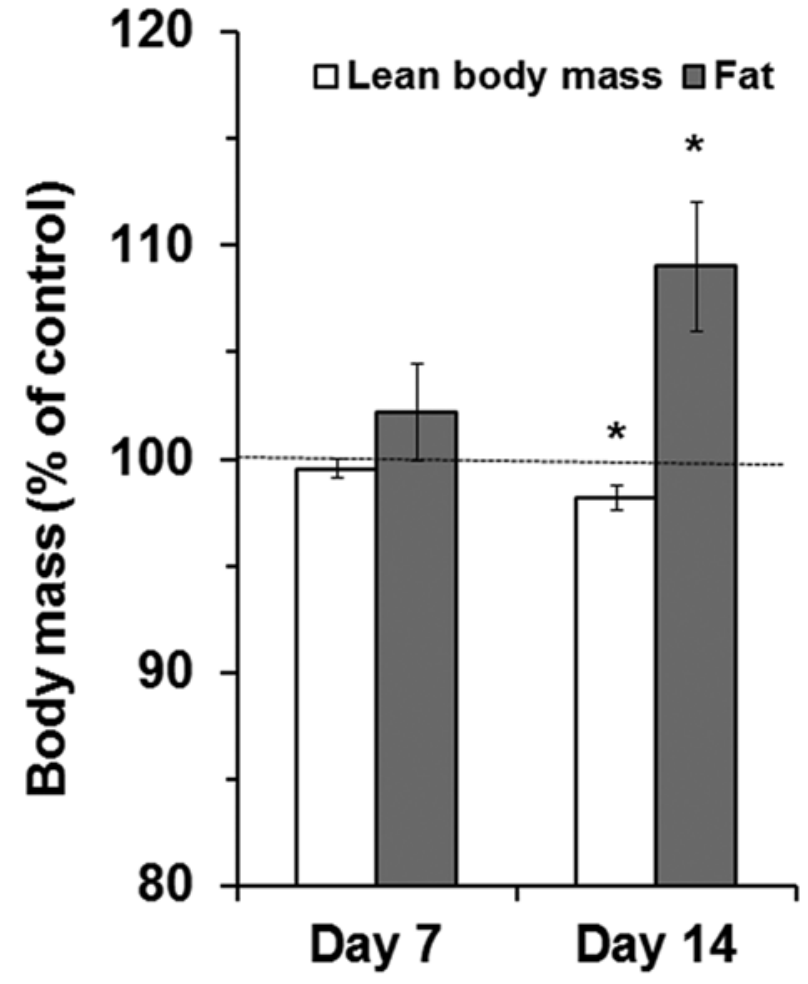

Figure 4.

Lean body mass and fat content of body at different time points based on PIXImus analysis. Values are percentage of group means and standard error of mean of the impacted compared with control mice. ${ }^{*}$ Significant at $p<0.05$ vs control mice based on $t$-test.

reduction in peak torque adjusted by cross-sectional area was significant $(31.3 \%, p=0.03)$ even though the bone size was not significantly different between the two treatment groups of mice, suggesting that the cortical bone of the impacted mice had reduced bone strength.

\section{Trabecular Architecture}

Micro-CT analysis of the metaphyseal region of the tibia showed that there was no significant difference in TV, consistent with the cortical bone data. However, there were significant reductions in BV $(25.3 \%, p<$ $0.001)$, BV per TV (BV/TV, 27.5\%, $p<0.001)$ and connectivity density $(42.9 \%, p<0.001)$ in the impacted mice (Figure 9). This was due to a decreased trabecular number (Tb.N) (7.8\%, $p=0.04)$ and trabecular thickness (7.7\%, $p<0.001)$ and increased trabecular separation (Tb.Sp) (10.1\%, $p=0.04)$. Histomorphometric analysis of the same tibial region showed similar results, i.e., no 


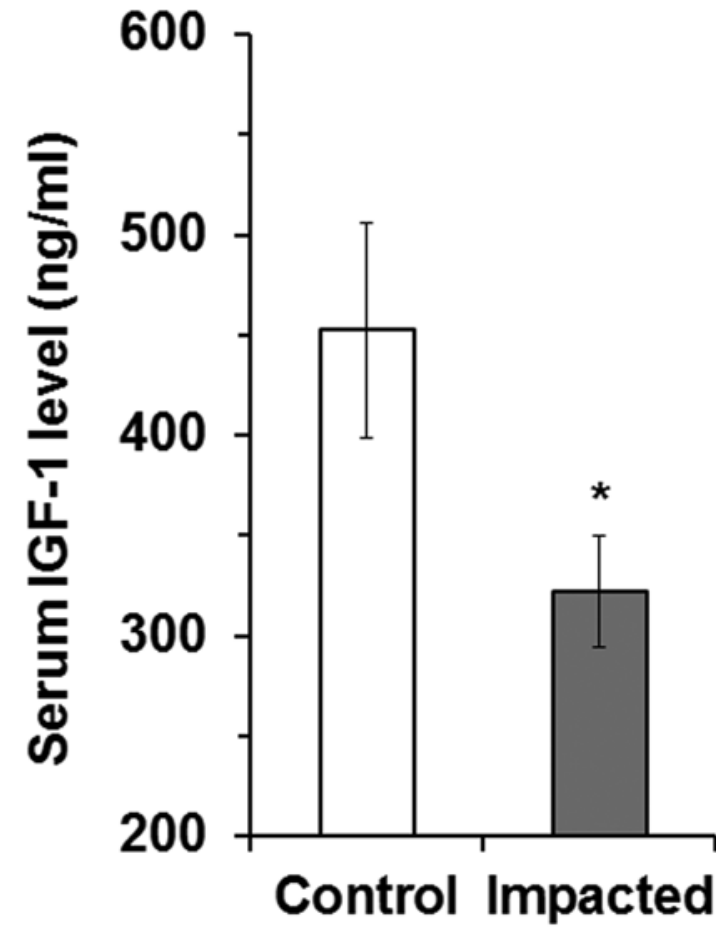

Figure 5.

Systemic insulin-like growth factor 1 (IGF-1) levels based on serum assay. Values are group means and standard error of mean. * Significant at $p<0.05$ vs control mice based on $t$-test.

change in total area (T.Ar), a significant or close to significant reductions in bone area $(36 \%, p=0.06)$, BV/TV $(40 \%, p=0.05)$ and Tb.N (37\%, $p=0.02)$, and a significant increase in Tb.Sp (83\%, $p=0.05)$ (Table 2). While the bone formation rate (BFR) per bone surface (BFR/ BS) did not show a significant difference, the BFR per T.Ar (BFR/T.Ar) was decreased by 34 percent in the impacted mice, even though this reduction was not significant $(p=0.07)$ (Figure 10).

\section{DISCUSSION}

In this study, the effect of repetitive mTBI was evaluated using a mouse model. The mTBI effect was measured histologically as well as through gene expression analysis using samples collected at $2 \mathrm{wk}$ after the first impact. One of the immediate effects in mTBI is brain microhemorrhage. Hemorrhagic volumes determined by a magnetic resonance imaging method with the distribution of extracellular iron as the result of following TBI was found to be (a)

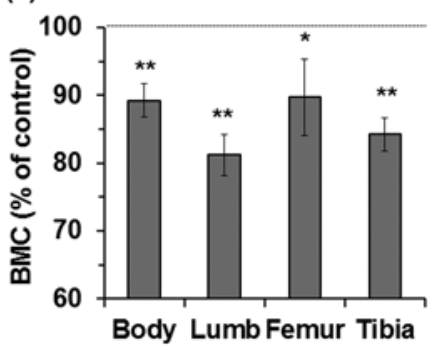

(b)

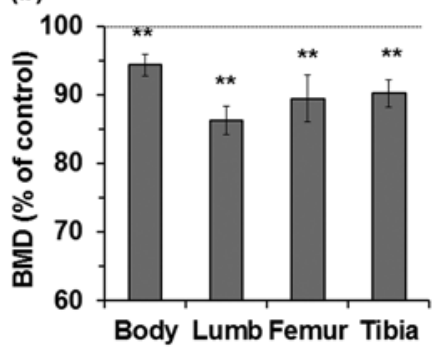

Figure 6.

Bone mass parameters of total body and specific bone sites based on PIXImus analysis. (a) Bone mineral content (BMC), (b) bone mineral density (BMD). Lumb = lumbar vertebrae. Values are percentage of group means and standard error of mean of impacted compared with control mice. ${ }^{*}$ Significant at $p<0.05$. ${ }^{* *}$ Significant at $p<0.01$ vs control mice based on $t$-test. (a)

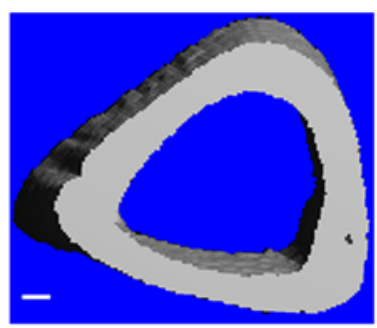

Control Tibia

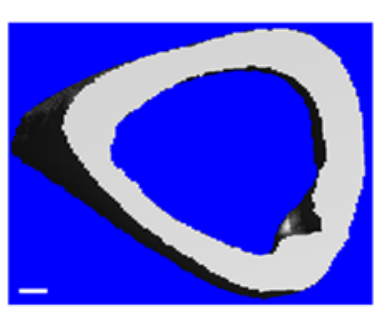

Impacted Tibia (b)

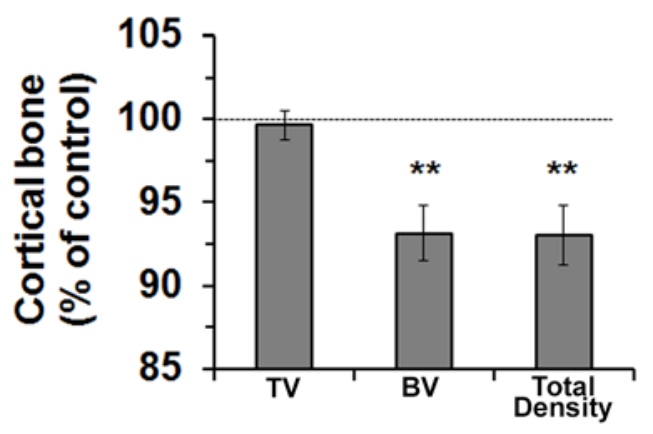

Figure 7.

Cortical bone structure at middiaphyseal region of tibia based on micro-computed tomography analysis. (a) Images of representative cross-sections of impacted and control mice. Calibration bar represents $100 \mu \mathrm{m}$. (b) Cortical bone parameters of impacted and control mice. All values are percentage of group means and standard error of mean of impacted compared with control mice. *Significant at $p<0.05$. ${ }^{*}$ Significant at $p<0.01$ vs control mice based on $t$-test. $\mathrm{BV}=$ bone volume, $\mathrm{TV}=$ total bone volume. 
(a)

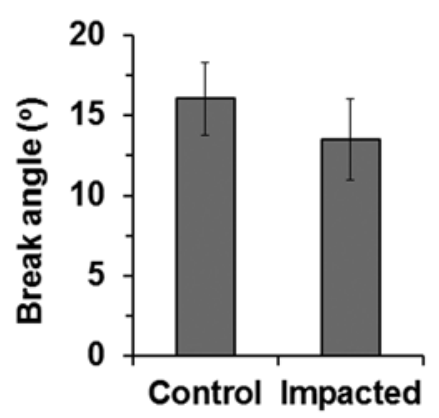

(b)

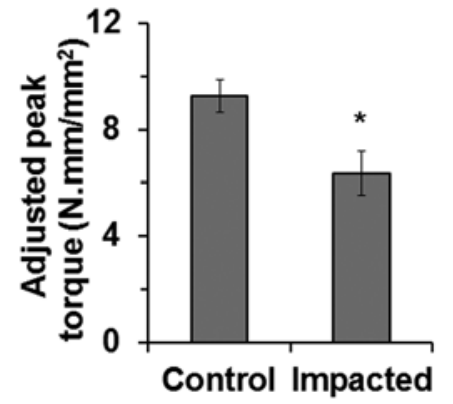

Figure 8.

Cortical bone strength of femur as determined by torsion testing. (a) Break angle at peak torque. (b) Adjusted peak torque by cross-sectional area at middiaphyseal region. All values are group means and standard error of mean. *Significant at $p<$ 0.05 vs control mice based on $t$-test.

correlated with red blood cell accumulation and degradation [34]. Although we indeed found significantly higher Prussian blue staining scores in the impacted versus control mice, indicating that the impact caused more iron deposition and hemorrhage, the Prussian blue staining was mostly localized in just a few areas beneath the impact area on the dorsal side and was not widespread in the brain. Cresyl violet staining is an effective and reliable method to determine the long-term neuronal survival following TBI [36-37]. No visible neuron damage was revealed with this stain, which was indicated by lack of amyloid accumulation and apoptotic neurons in the brain sections of the impacted and control mice. In addition, there was no significant difference in the number of neurons in brain sections between the two groups of mice.

The inflammatory and glial response of the brain to TBI impact was evaluated using real-time RT-PCR. The weight drop method is a diffuse injury model. Unlike a focal injury model such as the cortical contusion model, the impact is more likely to be widespread in the brain. This justifies our use of real-time RT-PCR to assess the reaction of the whole brain rather than the reaction of localized areas. We used two markers: IBA1 for microglia [38] and GFAP for astrocytes [39]. IBA1 is a gene that is upregulated upon the activation of microglia due to inflammation. Microglia are glial cells that are resident brain macrophages [40]. We did not observe significant changes in IBA1 expression in the impacted brain, suggesting a no or reduced inflammatory reaction and/or the (a)

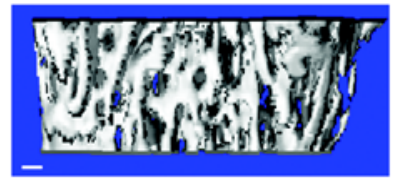

Control tibia

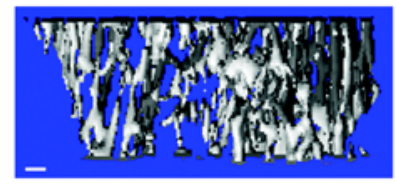

Impacted tibia (b)

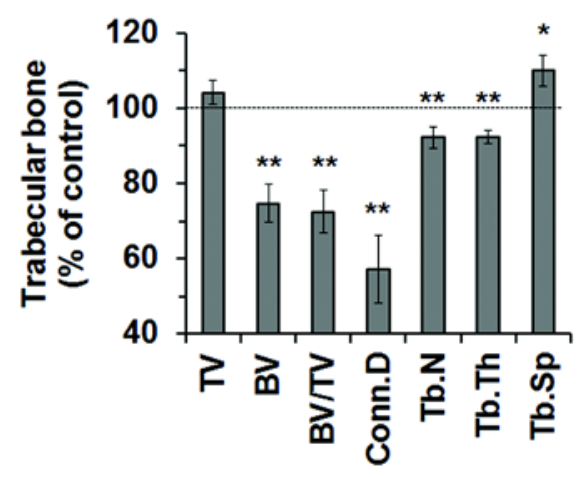

Figure 9.

Trabecular architecture at metaphyseal region of tibia based on micro-computed tomography analysis. (a) Images of representative cross-sections of impacted and control mice. Calibration bar represents $100 \mu \mathrm{m}$. (b) Trabecular bone parameters of impacted and control mice. All values are percentage of group means and standard errors of mean of impacted mice compared with control mice. ${ }^{*}$ Significant at $p<0.05$. ${ }^{\star *}$ Significant at $p<0.01$ vs control mice based on $t$-test. BV $=$ bone volume, Conn.D = connectivity density, Tb.N = trabecular number, Tb.Sp = trabecular separation, Tb.Th = trabecular thickness, $\mathrm{TV}=$ total bone volume.

mild nature of the trauma in this model. GFAP is a protein found in the astroglial cytoskeleton and can be used to measure the glial response following TBI. Astroglia are the most abundant type of glial cells, also called astrocytes, in the human brain [41]. The increased or "reactivated" astrocytes, in a process called astrocytosis, play a role in secondary injury following neurotrauma [42], and astrocytosis could be an early sign of chronic traumatic encephalopathy [27]. Serum GFAP levels predict the clinical outcome of mTBI in children [38]. Consistent with previous studies using immunochemical staining and immunoblot analysis [27,34], our real-time RT-PCR studies showed an increased expression of GFAP in the impacted compared with control brain, suggesting that secondary damage might have been underway. We also evaluated the expression of Hsp70, a stress-inducible heat shock protein. Hsp70 has an anti-inflammatory role in 
JRRD, Volume 51, Number 9, 2014

Table 2.

Trabecular bone parameters derived from histomorphometric analysis of metaphyseal region of tibia.

\begin{tabular}{llllcccc}
\hline \multicolumn{1}{c}{ Treatment } & $\boldsymbol{n}$ & T.Ar $\left(\mathbf{m m}^{\mathbf{2}}\right)$ & $\mathbf{B . A r}\left(\mathbf{m m}^{2}\right)$ & $\mathbf{B V} / \mathbf{T V}$ & Tb.Th $(\boldsymbol{\mu m})$ & Tb.Sp $(\boldsymbol{\mu m})$ & Tb.N $($ per $\mathbf{~ m m})$ \\
\hline Control & 9 & $0.86 \pm 0.05$ & $0.14 \pm 0.02$ & $17.57 \pm 2.90$ & $34.86 \pm 1.43$ & $193.7 \pm 26.82$ & $4.90 \pm 0.62$ \\
Impacted & 9 & $0.86 \pm 0.02$ & $0.09 \pm 0.02$ & $10.61 \pm 1.69$ & $33.40 \pm 1.53$ & $353.88 \pm 68.88$ & $3.07 \pm 0.38$ \\
$t$-Test $(p)$ & & 1.00 & 0.06 & 0.05 & 0.50 & 0.05 & 0.02 \\
\% of control & 100 & 64.06 & 60.38 & 95.81 & 182.68 & 62.58
\end{tabular}

$\mathrm{B} . \mathrm{Ar}=$ bone area, $\mathrm{BV} / \mathrm{TV}=$ bone volume per total bone volume, $\mathrm{T} . \mathrm{Ar}=$ total area, Tb.N = trabecular number, TB.Sp = trabecular separation, $\mathrm{TB} . \mathrm{Th}=$ trabecular thickness.

(a)

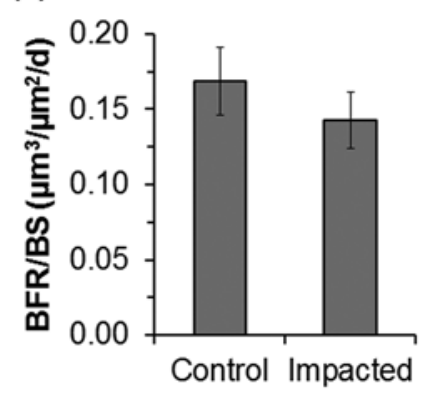

(b)

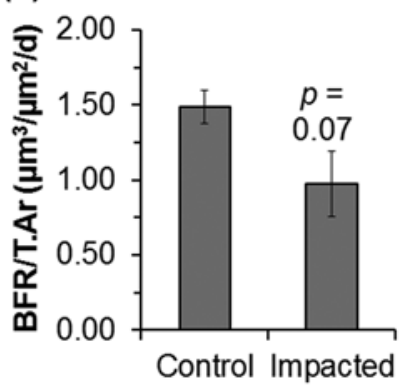

Figure 10.

Bone formation parameters at metaphyseal section of tibia obtained from histomorphometric analysis. (a) bone formation rate per bone surface (BFR/BS), (b) bone formation rate per total area (BFR/T.Ar). All values are group means and standard error of mean.

brain ischemia [43]. Previously, Hsp70 expression was shown to be increased following controlled cortical impact in a TBI mouse model, and it has a protective role in experimental TBI [44]. Here, we also found that Hsp70 gene expression was increased. Real-time RT-PCR indicated that at $2 \mathrm{wk}$ after the first impact, the inflammation caused by the impact had subsided and molecular changes leading to repair processes may have begun.

In this study, there were no significant changes in the body weight. However, we found that our repetitive mTBI model caused a significant increase in total body fat content and significant reductions in lean body mass and bone mass in the impacted mice. We speculate that increased immobilization because of TBI impact and/or molecular changes in the endocrine system could be contributing factors for these changes. In the endocrine system, TBI causes hypopituitarism, i.e., decreased secretion of pituitary hormones. Deficiency of the anterior pituitary hormone, $\mathrm{GH}$, is one of the most common forms of hypopituitarism [14]. Since circulating GH stimulates the production and secretion of IGF-1 in the liver, GH functions are primarily mediated through IGF-1, and IGF-1 is an anabolic hormone that stimulates the growth of nearly every cell in the body, IGF-1 can be used as a systemic indicator of TBI impact [45]. We measured the serum IGF-1 levels and found that mTBI impact caused a significant decrease at $2 \mathrm{wk}$ after the first impact. The decreased systemic IGF-1 levels would inevitably affect the growth and development of skeletal tissues.

We have previously evaluated the experimental TBI impact on skeletal tissues [26]. The negative effects included reduced bone mass accrual in total body and specific skeletal tissues, changes in cortical structure and trabecular architecture that would reduce their functionality, and reduced expression of bone formation marker genes. Consistent with that study, we found that repetitive mTBI also produced a negative effect on the skeletal system with a similar magnitude of change. However, the milder impact model in the current study caused no mortality and minimal visible damage to the brain compared with the significant mortality rate $(22 \%)$ caused by the weight drop impact in the previous study.

In order to determine whether the reduced bone mass in the impacted mice would influence bone strength, we used a torsion test, which measures mechanical strength in different orientations compared with three-point bending, which only measures bone strength in one orientation. We found that the strength of bone as measured by peak torque adjusted for bone size was significantly reduced in the impacted mice. The degree of the reduction was similar to our earlier results using three-point bending. These data suggest the mTBI-induced changes in the skeletal structure results in mechanically weaker bones.

Finally, we performed histomorphometric analyses of bone formation and resorption parameters in the tibial trabecular bone. The results seemed to suggest that the negative effects of mTBI on bone were contributed by reduced bone formation rather than increased bone resorption. These results were consistent with the expression analyses 
of bone formation and bone resorption marker genes in our previous study [26], which showed the downregulation of the bone formation marker gene, osteocalcin, and no increase in expression of bone resorption genes.

\section{CONCLUSIONS}

Repetitive mTBI in a mouse model caused a brain response characterized by microhemorrhage, moderate astrocytosis, no visible neuronal damage, and increased anti-inflammatory protective actions at $2 \mathrm{wk}$ after the first impact. Serum IGF-1 levels were significantly reduced, which could be one contributing factor for the observed significant negative effects mTBI exerted on bone mass, bone structure, and bone strength in the impacted mice. However, the long-term consequences and mechanisms of the mTBI impact on the skeletal system remain to be elucidated.

\section{ACKNOWLEDGMENTS}

\begin{abstract}
Author Contributions:
Study concept and design: H. Yu, S. Mohan.

Acquisition of data: $\mathrm{H}$. Yu.

Analysis and interpretation of data: H. Yu, S. Mohan.

Drafting of manuscript: H. Yu, S. Mohan.

Expert advisors and participants: J. E. Wergedal, C. H. Rundle.

Critical review of the manuscript: J. E. Wergedal, C. H. Rundle.

Financial Disclosures: The authors have declared that no competing interests exist.

Funding/Support: This material was based on work supported by the Rehabilitation Research and Development Merit Review Program of the VA (grant 1RX000175) and performed at research facilities provided by the VA Loma Linda HealthCare System.

Additional Contributions: The authors thank Heather Watt, Nancy Lowen, Catrina Alarcon, Joe Rung-Aroon, and Sheila Pourteymoor for their technical assistance. The authors thank Dr. Donna Strong for editing the manuscript.

Institutional Review: The project was approved by the Institutional Animal Care and Use Committee and the Institutional Biosafety Committee of the VA Loma Linda HealthCare System. All experimental protocols were in compliance with pertinent animal welfare regulations.
\end{abstract}

\section{REFERENCES}

1. Goodrich GL, Martinsen GL, Flyg HM, Kirby J, Asch SM, Brahm KD, Brand JM, Cajamarca D, Cantrell JL, Chong T, Dziadul JA, Hetrick BJ, Huang MA, Ihrig C, Ingalla SP, Meltzer BR, Rakoczy CM, Rone A, Schwartz E, Shea JE;
U.S. Department of Veterans Affairs. Development of a mild traumatic brain injury-specific vision screening protocol: A Delphi study. J Rehabil Res Dev. 2013;50(6):757-68. [PMID:24203539]

http://dx.doi.org/10.1682/JRRD.2012.10.0184

2. Powell JM, Ferraro JV, Dikmen SS, Temkin NR, Bell KR. Accuracy of mild traumatic brain injury diagnosis. Arch Phys Med Rehabil. 2008;89(8):1550-55.

[PMID:18597735]

http://dx.doi.org/10.1016/j.apmr.2007.12.035

3. Chamelian L, Reis M, Feinstein A. Six-month recovery from mild to moderate traumatic brain injury: The role of APOE-epsilon4 allele. Brain. 2004;127(Pt 12):2621-28.

[PMID:15496436]

http://dx.doi.org/10.1093/brain/awh296

4. Guskiewicz KM, Marshall SW, Bailes J, McCrea M, Cantu RC, Randolph C, Jordan BD. Association between recurrent concussion and late-life cognitive impairment in retired professional football players. Neurosurgery. 2005;57(4):719-26. [PMID:16239884] http://dx.doi.org/10.1227/01.NEU.0000175725.75780.DD

5. Pellman EJ, Viano DC, Casson IR, Tucker AM, Waeckerle JF, Powell JW, Feuer H. Concussion in professional football: Repeat injuries-part 4. Neurosurgery. 2004;55(4): 860-73, discussion 873-76. [PMID:15458594] http://dx.doi.org/10.1227/01.NEU.0000137657.00146.7D

6. Mouzon BC, Bachmeier C, Ferro A, Ojo JO, Crynen G, Acker CM, Davies P, Mullan M, Stewart W, Crawford F. Chronic neuropathological and neurobehavioral changes in a repetitive mild traumatic brain injury model. Ann Neurol. 2014;75(2):241-54. [PMID:24243523] http://dx.doi.org/10.1002/ana.24064

7. Petraglia AL, Plog BA, Dayawansa S, Chen M, Dashnaw ML, Czerniecka K, Walker CT, Viterise T, Hyrien O, Iliff JJ, Deane R, Nedergaard M, Huang JH. The spectrum of neurobehavioral sequelae following repetitive mild traumatic brain injury: a novel mouse model of chronic traumatic encephalopathy. J Neurotrauma. 2014;31(13):1211-24.

[PMID24766454]

http://dx.doi.org/10.1089/neu.2013.3255

8. Kiraly M, Kiraly SJ. Traumatic brain injury and delayed sequelae: A review-traumatic brain injury and mild traumatic brain injury (concussion) are precursors to lateronset brain disorders, including early-onset dementia. ScientificWorldJournal. 2007;7:1768-76. [PMID:18040539] http://dx.doi.org/10.1100/tsw.2007.269

9. Langlois JA, Rutland-Brown W, Wald MM. The epidemiology and impact of traumatic brain injury: A brief overview. J Head Trauma Rehabil. 2006;21(5):375-78.

[PMID:16983222]

http://dx.doi.org/10.1097/00001199-200609000-00001

10. Rosario ER, Aqeel R, Brown MA, Sanchez G, Moore C, Patterson D. Hypothalamic-pituitary dysfunction following 
traumatic brain injury affects functional improvement during acute inpatient rehabilitation. J Head Trauma Rehabil. 2013;28(5):390-96. [PMID:22613945] http://dx.doi.org/10.1097/HTR.0b013e318250eac6

11. Moon RJ, Sutton T, Wilson PM, Kirkham FJ, Davies JH. Pituitary function at long-term follow-up of childhood traumatic brain injury. J Neurotrauma. 2010;27(10):1827-35. [PMID:20684673] http://dx.doi.org/10.1089/neu.2010.1408

12. Tanriverdi F, De Bellis A, Ulutabanca H, Bizzarro A, Sinisi AA, Bellastella G, Amoresano Paglionico V, Dalla Mora L, Selcuklu A, Unluhizarci K, Casanueva FF, Kelestimur F. A five year prospective investigation of anterior pituitary function after traumatic brain injury: Is hypopituitarism long-term after head trauma associated with autoimmunity? J Neurotrauma. 2013;30(16):1426-33.

[PMID:23470214] http://dx.doi.org/10.1089/neu.2012.2752

13. Acerini CL, Tasker RC. Traumatic brain injury induced hypothalamic-pituitary dysfunction: A paediatric perspective. Pituitary. 2007;10(4):373-80. [PMID:17570066] http://dx.doi.org/10.1007/s11102-007-0052-8

14. Norwood KW, Deboer MD, Gurka MJ, Kuperminc MN, Rogol AD, Blackman JA, Wamstad JB, Buck ML, Patrick PD. Traumatic brain injury in children and adolescents: Surveillance for pituitary dysfunction. Clin Pediatr (Phila). 2010;49(11):1044-49. [PMID:20724335] http://dx.doi.org/10.1177/0009922810376234

15. Bassett JH, Williams GR. The molecular actions of thyroid hormone in bone. Trends Endocrinol Metab. 2003;14(8): 356-64. [PMID:14516933] http://dx.doi.org/10.1016/S1043-2760(03)00144-9

16. Bennetts JS, Rendtorff ND, Simpson F, Tranebjaerg L, Wicking C. The coding region of TP53INP2, a gene expressed in the developing nervous system, is not altered in a family with autosomal recessive non-progressive infantile ataxia on chromosome 20q11-q13. Dev Dyn. 2007;236(3): 843-52. [PMID:17238154] http://dx.doi.org/10.1002/dvdy.21064

17. Mohan S, Baylink DJ. Impaired skeletal growth in mice with haploinsufficiency of IGF-I: Genetic evidence that differences in IGF-I expression could contribute to peak bone mineral density differences. J Endocrinol. 2005;185(3): 415-20. [PMID:15930167] http://dx.doi.org/10.1677/joe.1.06141

18. Mohan S, Richman C, Guo R, Amaar Y, Donahue LR, Wergedal J, Baylink DJ. Insulin-like growth factor regulates peak bone mineral density in mice by both growth hormone-dependent and -independent mechanisms. Endocrinology. 2003;144(3):929-36. [PMID:12586770] http://dx.doi.org/10.1210/en.2002-220948

19. Xing W, Govoni KE, Donahue LR, Kesavan C, Wergedal J, Long C, Bassett JH, Gogakos A, Wojcicka A, Williams
GR, Mohan S. Genetic evidence that thyroid hormone is indispensable for prepubertal insulin-like growth factor-I expression and bone acquisition in mice. $\mathrm{J}$ Bone Miner Res. 2012;27(5):1067-79. [PMID:22513648]

http://dx.doi.org/10.1002/jbmr.1551

20. Ducy P, Amling M, Takeda S, Priemel M, Schilling AF, Beil FT, Shen J, Vinson C, Rueger JM, Karsenty G. Leptin inhibits bone formation through a hypothalamic relay: A central control of bone mass. Cell. 2000;100(2):197-207. [PMID:10660043] http://dx.doi.org/10.1016/S0092-8674(00)81558-5

21. Elefteriou F, Takeda S, Ebihara K, Magre J, Patano N, Kim CA, Ogawa Y, Liu X, Ware SM, Craigen WJ, Robert JJ, Vinson C, Nakao K, Capeau J, Karsenty G. Serum leptin level is a regulator of bone mass. Proc Natl Acad Sci USA. 2004;101(9):3258-63. [PMID:14978271] http://dx.doi.org/10.1073/pnas.0308744101

22. Takeda S, Elefteriou F, Levasseur R, Liu X, Zhao L, Parker KL, Armstrong D, Ducy P, Karsenty G. Leptin regulates bone formation via the sympathetic nervous system. Cell. 2002;111(3):305-17. [PMID:12419242] http://dx.doi.org/10.1016/S0092-8674(02)01049-8

23. Burguera B, Hofbauer LC, Thomas T, Gori F, Evans GL, Khosla S, Riggs BL, Turner RT. Leptin reduces ovariectomy-induced bone loss in rats. Endocrinology. 2001; 142(8):3546-53. [PMID:11459801] http://dx.doi.org/10.1210/endo.142.8.8346

24. Turner RT, Kalra SP, Wong CP, Philbrick KA, Lindenmaier LB, Boghossian S, Iwaniec UT. Peripheral leptin regulates bone formation. J Bone Miner Res. 2012;28(1):22-34. [PMID:22887758] http://dx.doi.org/10.1002/jbmr.1734

25. Driessler F, Baldock PA. Hypothalamic regulation of bone. J Mol Endocrinol. 2010;45(4):175-81. [PMID:20660619] http://dx.doi.org/10.1677/JME-10-0015

26. Yu H, Watt H, Mohan S. The negative impact of traumatic brain injury (TBI) on bone in a mouse model. Brain Inj. 2014;28(2):244-51. [PMID:24295038] http://dx.doi.org/10.3109/02699052.2013.859735

27. Kane MJ, Angoa-Pérez M, Briggs DI, Viano DC, Kreipke CW, Kuhn DM. A mouse model of human repetitive mild traumatic brain injury. J Neurosci Methods. 2012;203(1): 41-49. [PMID:21930157] http://dx.doi.org/10.1016/j.jneumeth.2011.09.003

28. Masinde GL, Li X, Gu W, Wergedal J, Mohan S, Baylink DJ. Quantitative trait loci for bone density in mice: The genes determining total skeletal density and femur density show little overlap in F2 mice. Calcif Tissue Int. 2002; 71(5):421-28. [PMID:12202954] http://dx.doi.org/10.1007/s00223-001-1113-z

29. Yu H, Watt H, Kesavan C, Johnson PJ, Wergedal JE, Mohan S. Lasting consequences of traumatic events on behavioral and skeletal parameters in a mouse model for 
post-traumatic stress disorder (PTSD). PLoS ONE. 2012; 7(8):e42684. [PMID:22927935]

http://dx.doi.org/10.1371/journal.pone.0042684

30. Mohan S, Baylink DJ. Development of a simple valid method for the complete removal of insulin-like growth factor (IGF)-binding proteins from IGFs in human serum and other biological fluids: Comparison with acid-ethanol treatment and C18 Sep-Pak separation. J Clin Endocrinol Metab. 1995;80(2):637-47. [PMID:7531716]

31. Yu H, Watt H, Kesavan C, Mohan S. The negative impact of single prolonged stress (SPS) on bone development in mice. Stress. 2013;16(5):564-70. [PMID:23682920]

http://dx.doi.org/10.3109/10253890.2013.806908

32. Yu H, Wergedal JE, Zhao Y, Mohan S. Targeted disruption of TGFBI in mice reveals its role in regulating bone mass and bone size through periosteal bone formation. Calcif Tissue Int. 2012;91(1):81-87. [PMID:22644324] http://dx.doi.org/10.1007/s00223-012-9613-6

33. Shen W, Finnegan S, Lein P, Sullivan S, Slaughter M, Higgins $\mathrm{D}$. Bone morphogenetic proteins regulate ionotropic glutamate receptors in human retina. Eur J Neurosci. 2004; 20(8):2031-37. [PMID:15450082] http://dx.doi.org/10.1111/j.1460-9568.2004.03681.x

34. Huang L, Coats JS, Mohd-Yusof A, Yin Y, Assaad S, Muellner MJ, Kamper JE, Hartman RE, Dulcich M, Donovan VM, Oyoyo U, Obenaus A. Tissue vulnerability is increased following repetitive mild traumatic brain injury in the rat. Brain Res. 2013;1499:109-20.

[PMID:23276495] http://dx.doi.org/10.1016/j.brainres.2012.12.038

35. Thompson SW. Selected histochemical and histopathological methods. Springfield (IL): Thomas; 1966.

36. Cao P, Liang Y, Gao X, Zhao MG, Liang GB. Administration of MS-275 improves cognitive performance and reduces cell death following traumatic brain injury in rats. CNS Neurosci Ther. 2013;19(5):337-45.

[PMID:23551690] http://dx.doi.org/10.1111/cns.12082

37. Shitaka Y, Tran HT, Bennett RE, Sanchez L, Levy MA, Dikranian K, Brody DL. Repetitive closed-skull traumatic brain injury in mice causes persistent multifocal axonal injury and microglial reactivity. J Neuropathol Exp Neurol. 2011;70(7):551-67. [PMID:21666502] http://dx.doi.org/10.1097/NEN.0b013e31821f891f

38. Ziebell JM, Taylor SE, Cao T, Harrison JL, Lifshitz J. Rod microglia: Elongation, alignment, and coupling to form trains across the somatosensory cortex after experimental diffuse brain injury. J Neuroinflammation. 2012;9:247.

[PMID:23111107] http://dx.doi.org/10.1186/1742-2094-9-247

39. Okonkwo DO, Yue JK, Puccio AM, Panczykowski DM, Inoue T, McMahon PJ, Sorani MD, Yuh EL, Lingsma HF, Maas AI, Valadka AB, Manley GT; Transforming Research and Clinical Knowledge in Traumatic Brain Injury (TRACK-TBI) Investigators. GFAP-BDP as an acute diagnostic marker in traumatic brain injury: Results from the prospective transforming research and clinical knowledge in traumatic brain injury study. J Neurotrauma. 2013;30(17): 1490-97. [PMID:23489259] http://dx.doi.org/10.1089/neu.2013.2883

40. Lawson LJ, Perry VH, Gordon S. Turnover of resident microglia in the normal adult mouse brain. Neuroscience. 1992;48(2):405-15. [PMID:1603325] http://dx.doi.org/10.1016/0306-4522(92)90500-2

41. Venkatesh K, Srikanth L, Vengamma B, Chandrasekhar C, Sanjeevkumar A, Mouleshwara Prasad BC, Sarma PV. In vitro differentiation of cultured human CD34+ cells into astrocytes. Neurol India. 2013;61(4):383-88.

[PMID:24005729] http://dx.doi.org/10.4103/0028-3886.117615

42. Laird MD, Vender JR, Dhandapani KM. Opposing roles for reactive astrocytes following traumatic brain injury. Neurosignals. 2008;16(2-3):154-64. [PMID:18253055] http://dx.doi.org/10.1159/000111560

43. Zheng Z, Kim JY, Ma H, Lee JE, Yenari MA. Anti-inflammatory effects of the $70 \mathrm{kDa}$ heat shock protein in experimental stroke. J Cereb Blood Flow Metab. 2008;28(1):53-63.

[PMID:17473852] http://dx.doi.org/10.1038/sj.jcbfm.9600502

44. Kim JY, Kim N, Zheng Z, Lee JE, Yenari MA. The 70 kDa heat shock protein protects against experimental traumatic brain injury. Neurobiol Dis. 2013;58:289-95.

[PMID:23816752] http://dx.doi.org/10.1016/j.nbd.2013.06.012

45. Kaulfers AM, Backeljauw PF, Reifschneider K, Blum S, Michaud L, Weiss M, Rose SR. Endocrine dysfunction following traumatic brain injury in children. J Pediatr. 2010; 157(6):894-99. [PMID:20797728] http://dx.doi.org/10.1016/j.jpeds.2010.07.004

Submitted for publication April 3, 2014. Accepted in revised form July 10, 2014.

This article and any supplementary material should be cited as follows:

Yu H, Wergedal JE, Rundle CH, Mohan S. Reduced bone mass accrual in mouse model of repetitive mild traumatic brain injury. J Rehabil Res Dev. 2014;51(9):1427-38.

http://dx.doi.org/10.1682/JRRD.2014.04.0095

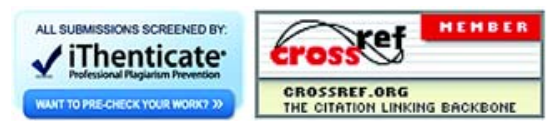


